\title{
Frequency and geographic distribution of TERT promoter mutations in primary hepatocellular carcinoma
}

\author{
Francesca Pezzuto, Luigi Buonaguro, Franco M. Buonaguro and Maria Lina Tornesello * [
}

\begin{abstract}
Primary hepatocellular carcinoma (HCC) mainly develops in subjects chronically infected with hepatitis B (HBV) and C $(\mathrm{HCV})$ viruses through a multistep process characterized by the accumulation of genetic alterations in the human genome. Nucleotide changes in coding regions (i.e. TP53, CTNNB1, ARID1A and ARID2) as well as in non-coding regions (i.e. TERT promoter) are considered cancer drivers for HCC development with variable frequencies in different geographic regions depending on the etiology and environmental factors. Recurrent hot spot mutations in TERT promoter ( $G>A$ at-124 bp; G > A at -146 bp), have shown to be common events in many tumor types including HCC and to up regulate the expression of telomerases. We performed a comprehensive review of the literature evaluating the differential distribution of TERT promoter mutations in 1939 primary HCC from four continents. Mutation rates were found higher in Europe (56.6\%) and Africa (53.3\%) than America (40\%) and Asia (42.5\%). In addition, HCV-related HCC were more frequently mutated (44.8\% in US and $69.7 \%$ in Asia) than HBV-related HCC (21.4\% in US and $45.5 \%$ in Africa). HCC cases associated to factors other than hepatitis viruses are also frequently mutated in TERT promoter $(43.6 \%, 52.6 \%$ and $57.7 \%$ in USA, Asia and Europe, respectively). These results support a major role for telomere elongation in HCV-related and nonviral related hepatic carcinogenesis and suggest that TERT promoter mutations could represent a candidate biomarker for the early detection of liver cancer in subjects with HCV infection or with metabolic liver diseases.
\end{abstract}

Keywords: Telomerase, TERT promoter mutations, Hepatocellular carcinoma, Hepatitis B virus, Hepatitis C virus

\section{Background}

Primary liver cancer is one of the commonest and deadliest malignancies in the world accounting for 782,000 new cases and 746,000 deaths in 2012 [1]. The highest incidence has been observed in men from Eastern and South-Eastern Asia (age standardized rates [ASR] 31.9 and 22.2 per 100,000, respectively) and in women from Eastern Asia and Western Africa (ASR 8.1 and 10.2 per 100,000 , respectively). On the other hand, liver cancer incidence is intermediate in southern Europe and northern America (ASR 9.5 and 9.3/100,000 men, respectively), and low in western and northern Europe (ASR $<7.5 / 100,000$ men and $<2.5 / 100,000$ women) [2].

Hepatocellular carcinoma (HCC) and intrahepathic cholangiocarcinoma (ICC) are the most common histotypes of primary liver cancer accounting for about $80 \%$

\footnotetext{
* Correspondence: irccsvir@unina.it; m.tornesello@istitutotumori.na.it Molecular Biology and Viral Oncology Unit, Istituto Nazionale Tumori IRCCS "Fondazione G Pascale", 80131 Napoli, Italy
}

and $15 \%$, respectively, of all cases worldwide [3-5]. HCC and ICC mainly develops in patients with liver cirrhosis caused by chronic infection with hepatitis B (HBV) and hepatitis $\mathrm{C}(\mathrm{HCV})$ or caused by alcohol excess, as well as in patients with non-alcoholic fatty liver disease or other metabolic liver disorders [6]. HBV chronically infects more than 300 million people in the world, mainly in Asia and Africa, while HCV infects approximately 180 million people, mostly in Japan, Europe and United States [6]. Accordingly, HBV-related HCC are more frequent in Asia and Africa (above $50 \%$ of all cases), while HCV-related HCC are predominant in Europe and USA (35-50\% of all cases) $[2,7,8]$.

The complex multistep process of liver carcinogenesis includes inflammation, hepatic damage, cirrhosis, increased liver fibrosis and HCC [9-11]. The molecular mechanisms involved in the malignant transformation of hepatocytes are extremely complex and comprise numerous genetic and epigenetic alterations [12, 13]. Genome instability, 
mainly involving gains in chromosomes 1q, 5, 6p, 7, 8q, $17 \mathrm{q}$ and 20 and losses in chromosomes 1p, 4q, 6q, 8p, 13q, $16,17 \mathrm{p}$ and 21 , has been observed in more than $80 \%$ of HCC associated to chronic viral hepatitis [14-17].

Several lines of evidence suggest that the pattern of somatic mutations in liver cancer varies in different geographic regions very likely depending on environmental factors or host genetic diversity [18-21]. Indeed, tumor protein 53 (TP53) coding gene mutations in HCC have been observed to occur most commonly in sub-Saharan Africa and Southeast Asia, where the combination of dietary aflatoxin B1 (AFB1) exposure and hepatitis B infection promotes high rate of mutagenesis in the liver [22]. More recently, several new recurrent mutations affecting genes involved in cell cycle regulation and chromatin remodeling have been discovered by whole exome sequencing technology and found differentially distributed in different populations [23-26].

Moreover, the analysis by whole-genome sequencing allowed to discover a substantial fraction of recurrent somatic mutations in non-coding regions of human genome with important regulatory effects on the gene expression in cancer [27]. The most notable example has been the identification of hot spot activating mutations in the promoter region of telomerase reverse transcriptase (TERT) gene in about $85 \%$ of human tumors, including liver cancer [28-31]. The newly described mutations at nucleotides 124 (mostly $\mathrm{G}>\mathrm{A}$ and rarely $\mathrm{G}>\mathrm{T}$ ) or 146 ( $\mathrm{G}>\mathrm{A}$ ) before the ATG start site in TERT promoter region have been recognized as frequent and early alterations in the hepatic carcinogenesis [31, 32]. These mutations create a binding site for transcription factors ETS (E-twenty six) and ternary complex factor (TCF), causing TERT over expression and restoring the telomerase activity [33].

Moreover, the single nucleotide polymorphism rs2853669, located at -245 bp upstream of the ATG start codon in TERT promoter, has also shown to deregulate the expression levels of TERT mRNA [34].

We performed a systematic review of published studies to investigate the frequency of TERT promoter mutations in 1939 HCC with diverse etiologies. Moreover, we evaluated the mutational pattern of TERT promoter in tumors from different geographic areas to possibly correlate the type of nucleotide changes with specific environmental or genetic factors in different regions of the world.

\section{Telomerase and liver diseases}

TERT gene encodes for the catalytic subunit of the telomerase reverse transcriptase which is an RNA-dependent DNA polymerase highly expressed in germ cells, in stem cells and in cancer cells $[35,36]$. The telomerase synthesizes telomeres which are long stretches of 5'TTAGGG-3' DNA repeats ending in a single-strand 3' G-rich sequence located at the extremities of human chromosomes. Telomeres protect chromosomes from degradation, end-to-end fusion and recombination and act as an internal clock by regulating the maximal number of cell replication and aging [37-43].

The pathogenesis of liver diseases is strongly dependent on telomeres length and telomerase expression [44]. Several studies have shown a relationship between cirrhosis and telomeres attrition suggesting that this event could be considered a marker of cirrhosis [45-47]. However, telomerase activity and telomere elongation is restored in up to $90 \%$ of HCC, compared to the $21 \%$ of adjacent non-tumor tissues [8, 48-50]. Moreover, long telomeres and increased telomerase levels have shown to be associated with aggressive HCC phenotype and with poor prognosis [51].

Telomerase is activated by different mechanisms during liver carcinogenesis. In HBV related HCC the telomerase reactivation is frequently caused by the insertion of the HBV DNA within or upstream the TERT gene [52-56]. Sung et al. identified integrated HBV DNA in $86.4 \%$ of liver cancers, by whole-genome deep sequencing, and found that genes recurrently affected by HBV integration were TERT (23.7\%), myeloid/lymphoid or mixed-lineage leukemia 4 (MLL4) gene (11.8\%) and cyclin E1 encoding gene (CCNE1) (5.2\%) [57]. Totoki et al. performed a comprehensive transancestry liver cancer genome study on 506 HCC cases from Asia and USA and observed HBV integration in TERT locus in 22\% of tumors [31]. Moreover, they observed that TERT promoter mutations were in general mutually exclusive with HBV genome integration in the TERT locus and with TERT focal amplification, suggesting that either event is sufficient to activate telomerases. In addition, Zhao et al. reported that HBV insertional sites are significantly enriched in the proximity of telomeres in HCC DNA but not in non-tumor cell genomes suggesting that the integrated virus in cancer tends to target chromosomal elements critical for the maintenance of chromosome stability [58]. Moreover, Yang et al. analyzed 2199 HBV integration sites and observed that affected genes included $23.1 \%$ of protein-coding genes and $24.7 \%$ of long noncoding RNAs (lncRNA) [59]. Interestingly, the most frequently lncRNA genes affected by HBV integration were related to telomere maintenance, protein modification processes, and chromosome localization [59].

In HCV-related HCC and non-viral related HCC the telomerase activation is due to TERT promoter mutations in $40 \%$ to $75 \%$ of HCC cases, however with a considerable variation in different cohorts, as detailed in the next section.

\section{TERT promoter mutations in different geographical regions}

Published data on the analysis of TERT promoter mutations in liver cancer were searched in Medline using the terms ("hepatocellular" OR ("Liver" AND "Cancer")) AND ("TERT" OR "telomerase") AND ("Promoter") 
AND ("mutation" OR "variation"), (Fig. 1). For the studies that involved more than one geographic location the data were divided into components for each continent. The search was updated on 31 January 2017.

The frequencies of TERT mutations in HCC have shown to vary by cancer etiology and geographic patient provenance (Table 1). Cevik et al. analyzed TERT promoter mutations in $15 \mathrm{HCC}$ cases from Africa [60]. African patients comprised mainly HBV-positive subjects from Mozambique $(n=6)$, Transkei $(n=4)$, Lesotho $(n=$ $2)$, Swaziland $(n=1)$ and South Africa $(n=2)$. The overall frequency of TERT promoter mutation among the HCC African cases was $53.3 \%$ and in the subgroup of HBVrelated $\mathrm{HCC}$ was $45.5 \%$. No other study has analyzed the TERT promoter mutation pattern in African HCC and more cases need to be analyzed to confirm such results.

Two studies evaluated TERT promoter mutations among $150 \mathrm{HCC}$ cases from the United States and the overall mutation rate was $40 \%[31,61]$. The HCV-related HCC and non viral related cases, mainly associated to alcohol and metabolic syndrome, were more mutated $(44.7 \%$ and $43.6 \%$, respectively) compared to HBV-related cases (21.4\%), Table 1. Both USA cohorts comprised patients with European ancestry $(n=74)$, Asian ancestry $(n=22)$ and African-American ancestry $(n=23)$. Comparable frequencies of TERT promoter mutations were observed between European (43.6\%) and African (37.5\%) HCV-related HCC. Larger studies are warranted in the USA to analyze the TERT variation frequencies in HBV-related and no-virus related $\mathrm{HCC}$ and to determine whether the genetic background has a role in the accumulation of TERT mutations in $\mathrm{HCC}$ in this multiethnic population.

In Asia, a total of 1014 HCC have been analyzed for TERT promoter nucleotide changes comprising 396 cases from Japan, 318 from China, 195 from Taiwan and 105 from South Korea. The overall mutation frequencies in TERT promoter were $28.9 \%$ in $\mathrm{HBV}$-positive, $69.7 \%$ in HCV-related and 52.6\% in non viral related HCC (Table 1). However, there were significant differences between mutation rates observed in $\mathrm{HCV}$-related and no virus related HCC in Japan (74.8\% and 62.4\%, respectively) and South Korea (83.3\% and 61.9\%) versus Taiwan (54\% and 20.8\%). Similarly, variable rates of TERT mutations were observed among HBV positive HCC with high frequency in Japan (37.4\%), intermediate in China (30.1\%) and South Korea (29.4\%) and low in Taiwan (20.6\%).

In Europe, among the $760 \mathrm{HCC}$ analyzed in five studies a total of $430(56.6 \%)$ cases were found mutated in TERT promoter. The proportion of hot spot mutations in $\mathrm{HCV}$, no virus and $\mathrm{HBV}$ related $\mathrm{HCC}$ was $61.5 \%$, $57.7 \%$ and $42.7 \%$, respectively. The highest mutation rate was observed in $\mathrm{HCV}$-positive $(73.1 \%)$ and other etiology HCC (61.7\%), mainly related to alcohol, in France. In Italy, lower rates of TERT promoter mutations were observed in $\mathrm{HCV}$-positive $\mathrm{HCC}$, ranging from $40 \%$ to $53.6 \%$, and in $\mathrm{HBV}$-positive $\mathrm{HCC}$, ranging from $70 \%$ to $41.6 \%$, from northern and southern Italy patients, respectively.

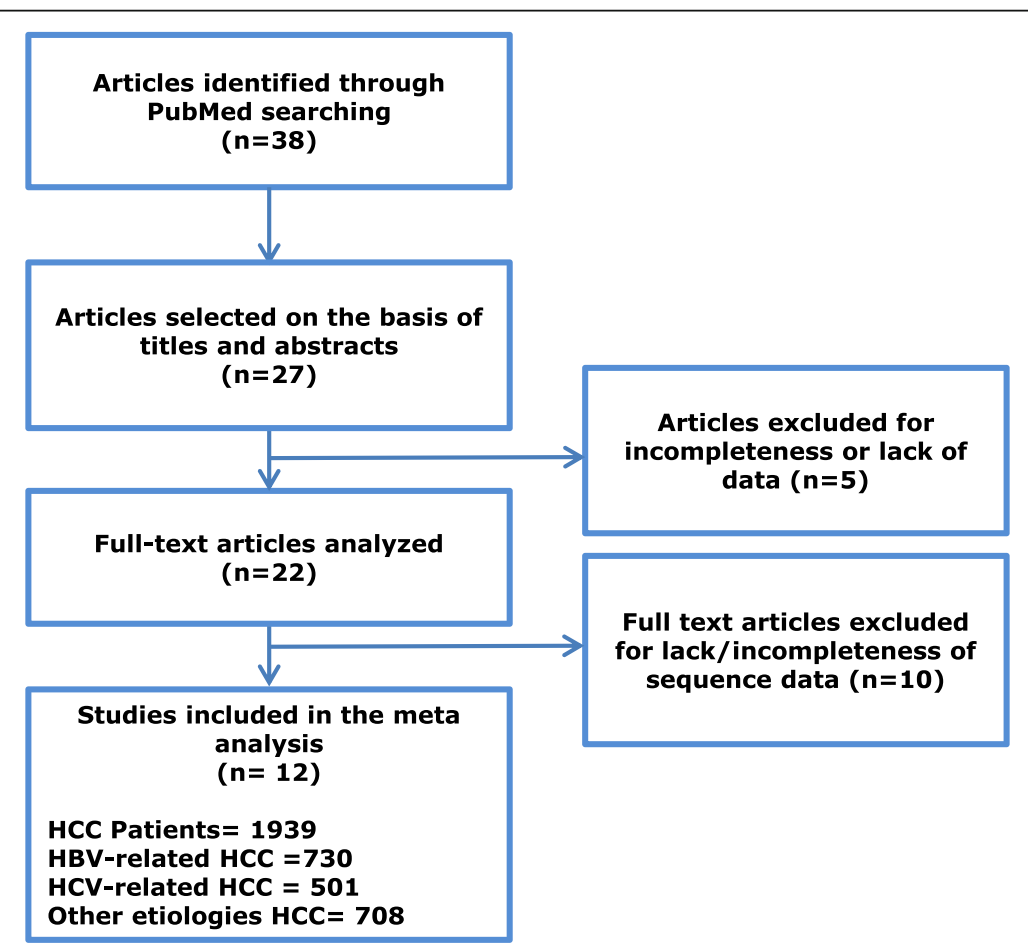

Fig. 1 Flow diagram of selected articles and inclusion in the meta analysis 


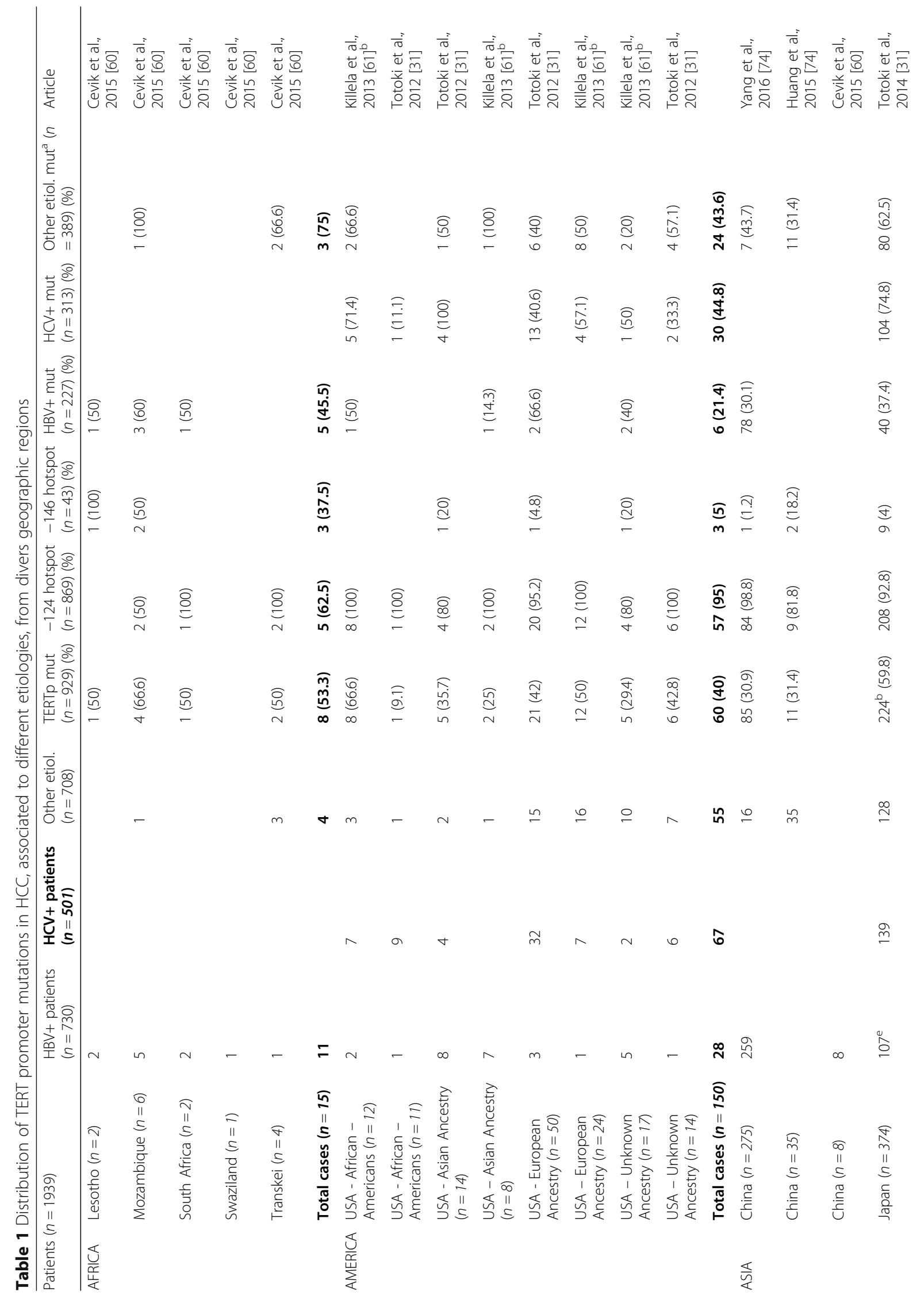




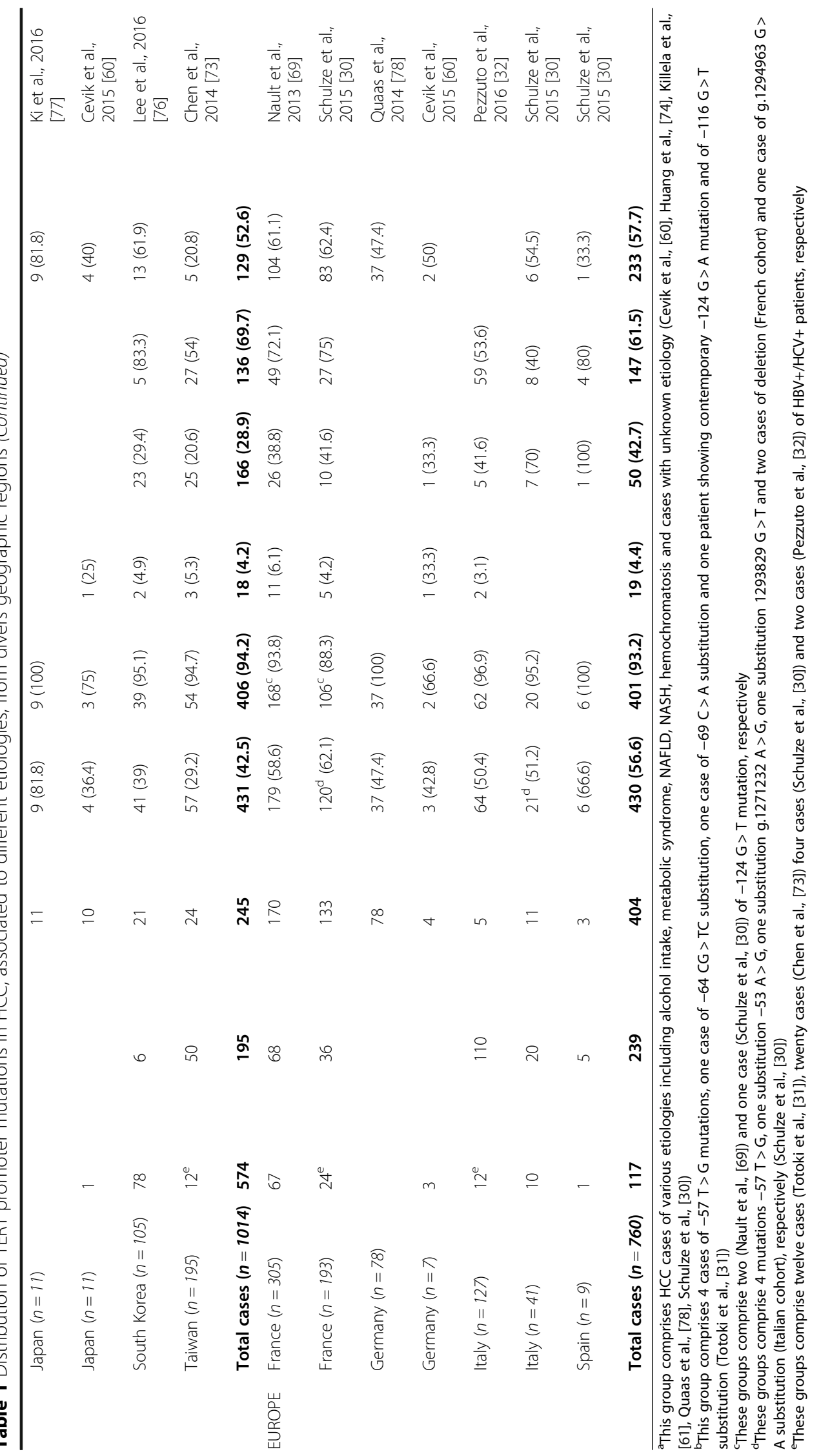


In all studies the activating mutation at nucleotide $-124 \mathrm{G}>\mathrm{A}$ was more frequent than the mutation at position $-146 \mathrm{G}>\mathrm{A}$ (93.4\% versus $4.6 \%$, respectively).

\section{TERT promoter mutation and rs2853669 polymorphism}

Several studies have reported that the single nucleotide polymorphism (SNP) rs2853669 allele G, located at nucleotide -245 from the TERT ATG start site, down regulates the expression of TERT gene caused by hot spot promoter mutations in several types of cancer including bladder, gliomas, and renal cell cancer $[62,63]$. In the general population the rs2853669 allele $G$ is less frequent than allele A, except for the south Asia population where it has been observed the reverse [64] (www.ncbi.nlm.nih.gov/projects/SNP/snp_ref.cgi?rs=2853669).

Only two studies evaluated the rs2853669 polymorphism and TERT promoter mutations in liver cancer. The study by Pezzuto et al., analyzed the allele frequency of TERT SNP rs2853669 in HCC from Southern Italy patients and showed allele frequencies of $51 \% \mathrm{~A}$ and 48.9\% $\mathrm{G}$ among the TERT promoter mutated HCC and $57.6 \% \mathrm{~A}$ and $42.4 \% \mathrm{G}$ among non-mutated cancer cases [32]. Although $G$ allele appeared more frequent among TERT mutated cases, such difference did not reach statistical significance. Moreover, the Log-rank survival analysis showed no correlation between the presence of TERT promoter mutations, alone or in combination with rs2853669 GG and GA genotypes, and poor prognosis $(p=0.368)$ [32].

Ko et al. analyzed the impact of rs2853669 polymorphism in a cohort of south Korean HCC patients and observed no effect on the overall and recurrence-free survival. However, the combination of rs2853669 $\mathrm{G}$ allele and mutation in the TERT promoter was associated with poor survival [65]. Moreover, they showed that the rs2853669 nucleotide $\mathrm{G}$ causes increased binding of the transcription factor ETS2 to the TERT promoter and lower activity of the transcription inhibitor E2F1. This condition favors TERT promoter methylation and increased expression of telomerases [65]. Methylation of TERT promoter has been observed in several tumors and transformed cell lines and has been reported to correlate with TERT over expression and poor survival $[66,67]$.

\section{Discussion}

Telomerase activity has been found strongly up regulated in many human cancers including $\mathrm{HCC}$, highlighting its pivotal role in the neoplastic process $[28,48,49,68]$. TERT promoter mutations have been recognized as the earliest and most frequent genetic alterations in liver cancer $[25,31,69]$. We have summarized the TERT promoter mutation distribution in HCC cases, associated to different etiologies, from various geographic regions.

In Africa, where $\mathrm{HCC}$ cases are mainly related to $\mathrm{HBV}$ infection and AFB1 dietary exposure, the frequency of TERT promoter mutations is around 53\%. It is not known if there is synergistic effect between AFB1 and HBV on the accumulation of mutations in TERT as observed for the $G$ to $T$ variation at codon 249 in TP53 gene, specifically caused by HBV and AFB1 [70-72]. Interestingly, in USA where patients have no AFB1 exposure, the frequency of TERT promoter mutations

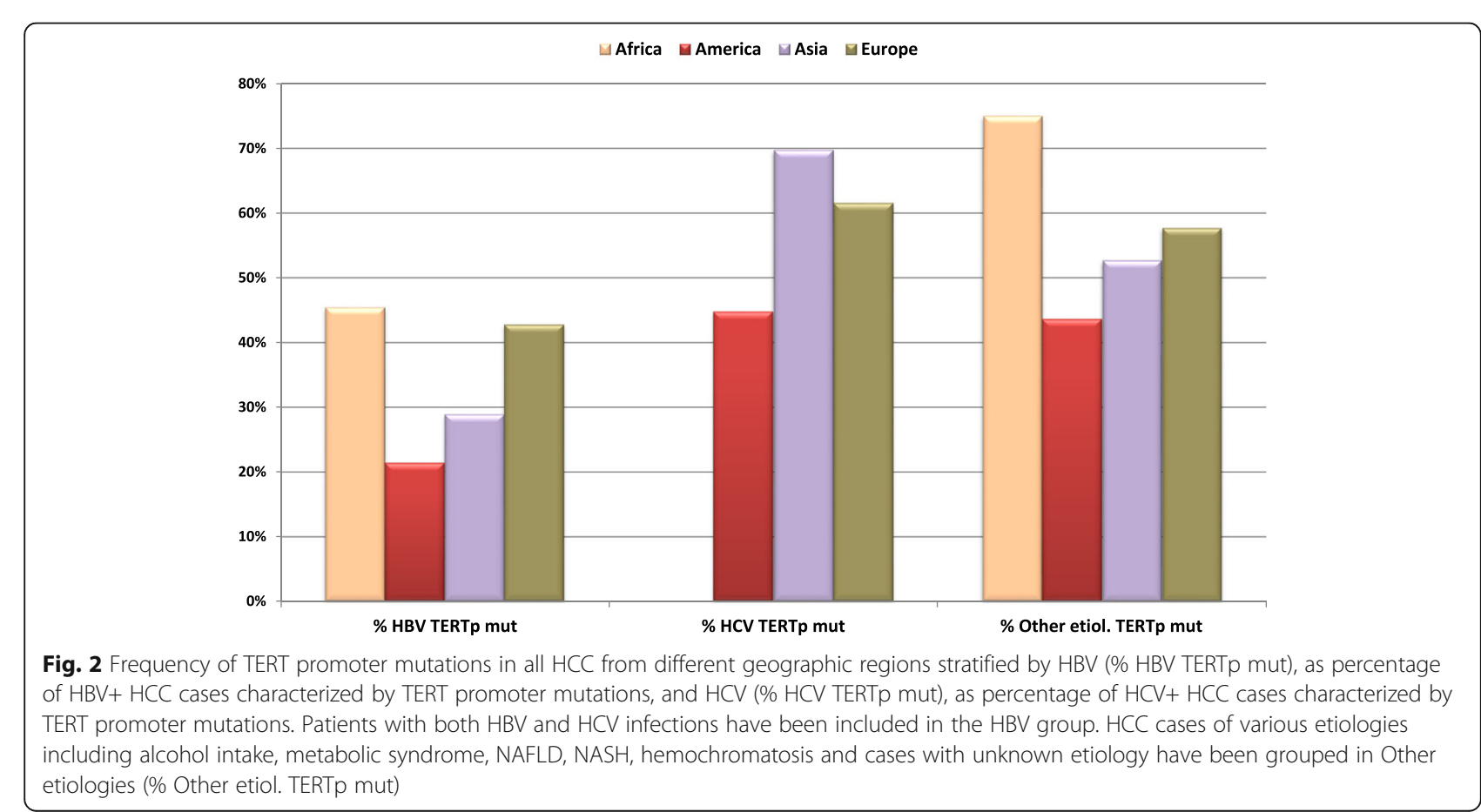


among HBV-positive cases is $21.4 \%$ [31, 61]. In Asia, the overall rate is $42.5 \%$ with lower frequencies in China and Taiwan [31, 60, 73-77]. Higher frequencies of TERT promoter mutations, ranging from $42.8 \%$ to $66.6 \%$, have been observed in Europe [30, 32, 60, 69, 78].

As shown in Fig. 2, HCV positive HCC have in general higher TERT promoter mutations rates than HBV positive tumors, in which TERT over expression is frequently caused by HBV integration [31, 32, 60, 73, 74]. HCC caused by non viral factors, such as alcohol consumption, metabolic syndrome, nonalcoholic fatty liver disease (NAFLD), nonalcoholic steatohepatitis (NASH), hemochromatosis, have a striking high frequency of mutation in TERT promoter. In fact, Ki et al. showed that in Japan $81.8 \%$ of NAFLD related HCC were mutated in TERT promoter [77]. In Europe, Nault et al. reported TERT promoter mutations in $68 \%$ of alcohol related HCC and in $63 \%$ of hemochromatosis related HCC cases [69].

Interestingly, TERT promoter mutations were more frequent in older patients $[69,73]$, and often associated with activating mutations in catenin beta 1 coding gene (CTNNB1) suggesting a cooperation between telomerase activity and $\beta$-catenin pathway [69].

\section{Conclusions}

In conclusion, TERT promoter mutations are very frequent in HCC with different etiologies and are tumor specific given their constant absence in non-tumor tissues. There is a substantial heterogeneity in the mutation frequency in HCC from different geographic regions, probably due to environmental factors, such as AFB1, and lifestyle, such as habit of alcohol consumption. The high proportion of HCC mutated cases in different geographic regions and the earliness of occurrence of TERT mutations during hepatocarcinogenesis suggest the use of this reliable biomarker for early HCC diagnosis and as possible target for specific therapies.

\section{Abbreviations \\ AFB1: Aflatoxin B1; ARID1A: AT-rich interaction domain 1A coding gene; ARID2: AT-rich interaction domain 2 coding gene; CCNE1: Cyclin E1 coding gene; CTNNB1: catenin beta 1 coding gene; ETS: E-twentysix; HBV: Hepatitis B virus; HCC: Hepatocellular carcinoma; HCV: Hepatitis C virus; ICC: Intrahepathic cholangiocarcinoma; IncRNA: Long noncoding RNAs; MLL4: Myeloid/lymphoid or mixed-lineage leukemia 4; NAFLD: Nonalcoholic fatty liver disease; NASH: Nonalcoholic steatohepatitis; TCF: Ternary complex factor; TERT: Telomerase reverse transcriptase coding gene; TP53: Tumor Protein 53 coding gene}

\section{Acknowledgements}

F. Pezzuto is the recipient of a research fellowship awarded by FIRE/AISF ONLUS (Fondazione Italiana per la Ricerca in Epatologia) http:// www.fondazionefegato.it/

\section{Funding}

This work was supported by grants from Ministero della Salute Ricerca Corrente 2013-2016 and Ricerca Finalizzata FN 270/RF-2010-2312010.

\section{Availability of data and material}

All data generated or analyzed during this study are included in this published article.

\section{Authors' contributions}

MLT designed the study and drafted the article; FP conducted the meta analysis and wrote the article; LB contributed to the statistical analyses; FMB supervised the whole project. All authors read and approved the final manuscript.

\section{Competing interests}

The authors declare that they have no competing interests.

\section{Consent for publication}

Not applicable.

Ethics approval and consent to participate

Not applicable.

\section{Publisher's Note}

Springer Nature remains neutral with regard to jurisdictional claims in published maps and institutional affiliations.

Received: 6 February 2017 Accepted: 11 May 2017

Published online: 19 May 2017

\section{References}

1. Ferlay J, Soerjomataram I, Ervik M, Dikshit R, Eser S, Mathers C, Rebelo M, Parkin DM, Forman D, Bray F. GLOBOCAN 2012 v1.0, Cancer Incidence and Mortality Worldwide: IARC CancerBase No. 11. Lyon, France: International Agency for Research on Cancer; 2013.

2. Bosetti C, Turati F, La VC. Hepatocellular carcinoma epidemiology. Best Pract Res Clin Gastroenterol. 2014;28:753-70.

3. Perz JF, Armstrong GL, Farrington LA, Hutin YJ, Bell BP. The contributions of hepatitis $B$ virus and hepatitis $C$ virus infections to cirrhosis and primary liver cancer worldwide. J Hepatol. 2006;45:529-38.

4. Okuda K, Nakanuma Y, Miyazaki M. Cholangiocarcinoma: recent progress, Part 1: epidemiology and etiology. J Gastroenterol Hepatol. 2002;17:1049-55.

5. Petrick JL, Braunlin M, Laversanne M, Valery PC, Bray F, McGlynn KA. International trends in liver cancer incidence, overall and by histologic subtype, 1978-2007. Int J Cancer. 2016;139:1534-45.

6. El-Serag HB. Epidemiology of viral hepatitis and hepatocellular carcinoma. Gastroenterology. 2012;142:1264-73.

7. Raza SA, Clifford GM, Franceschi S. Worldwide variation in the relative importance of hepatitis B and hepatitis C viruses in hepatocellular carcinoma: a systematic review. Br J Cancer. 2007;96:1127-34.

8. Protzer U, Maini MK, Knolle PA. Living in the liver: hepatic infections. Nat Rev Immunol. 2012:12:201-13.

9. Arzumanyan A, Reis HM, Feitelson MA. Pathogenic mechanisms in HBV- and HCV-associated hepatocellular carcinoma. Nat Rev Cancer. 2013;13:123-35.

10. Farazi PA, DePinho RA. Hepatocellular carcinoma pathogenesis: from genes to environment. Nat Rev Cancer. 2006:6:674-87.

11. Tornesello ML, Buonaguro L, Buonaguro FM. An overview of new biomolecular pathways in pathogen-related cancers. Future Oncol. 2015;11:1625-39.

12. Zucman-Rossi J, Villanueva A, Nault JC, Llovet JM. Genetic Landscape and Biomarkers of Hepatocellular Carcinoma. Gastroenterology. 2015;149:1226-39.

13. Tornesello ML, Buonaguro L, Izzo F, Buonaguro FM. Molecular alterations in hepatocellular carcinoma associated with hepatitis B and hepatitis C infections. Oncotarget. 2016;7:25087-102.

14. Guichard C, Amaddeo G, Imbeaud S, Ladeiro Y, Pelletier L, Maad IB, Calderaro J, Bioulac-Sage P, Letexier M, Degos F, Clement B, Balabaud C, Chevet E, Laurent A, Couchy G, Letouze E, Calvo F, Zucman-Rossi J. Integrated analysis of somatic mutations and focal copy-number changes identifies key genes and pathways in hepatocellular carcinoma. Nat Genet. 2012:44:694-8.

15. Thorgeirsson SS, Grisham JW. Molecular pathogenesis of human hepatocellular carcinoma. Nat Genet. 2002;31:339-46.

16. Chochi Y, Kawauchi S, Nakao M, Furuya T, Hashimoto K, Oga A, Oka M, Sasaki K. A copy number gain of the $6 p$ arm is linked with advanced hepatocellular carcinoma: an array-based comparative genomic hybridization study. J Pathol. 2009;217:677-84

17. Midorikawa Y, Yamamoto S, Tsuji S, Kamimura N, Ishikawa S, Igarashi H, Makuuchi M, Kokudo N, Sugimura H, Aburatani H. Allelic imbalances and homozygous deletion on $8 \mathrm{p} 23.2$ for stepwise progression of hepatocarcinogenesis. Hepatology. 2009;49:513-22. 
18. Tornesello ML, Buonaguro L, Tatangelo F, Botti G, Izzo F, Buonaguro FM. Mutations in TP53, CTNNB1 and PIK3CA genes in hepatocellular carcinoma associated with hepatitis B and hepatitis C virus infections. Genomics. 2013;102:74-83.

19. Unsal H, Yakicier C, Marcais C, Kew M, Volkmann M, Zentgraf H, Isselbacher KJ, Ozturk M. Genetic heterogeneity of hepatocellular carcinoma. Proc Natl Acad Sci U S A. 1994;91:822-6.

20. De Re V, Caggiari L, De ZM, Repetto O, Zignego AL, Izzo F, Tornesello ML, Buonaguro FM, Mangia A, Sansonno D, Racanelli V, De VS, Pioltelli P, Vaccher E, Berretta M, Mazzaro C, Libra M, Gini A, Zucchetto A, Cannizzaro R, De PP, 10. Genetic diversity of the KIR/HLA system and susceptibility to hepatitis C virus-related diseases. PLoS One. 2015;\%20:e0117420.

21. De Re V, De ZM, Caggiari L, Lauletta G, Tornesello ML, Fognani E, Miorin M, Racanelli V, Quartuccio L, Gragnani L, Russi S, Pavone F, Ghersetti M, Costa EG, Casarin P, Bomben R, Mazzaro C, Basaglia G, Berretta M, Vaccher E, Izzo F, Buonaguro FM, De VS, Zignego AL, De PP, Dolcetti R. HCV-related liver and lymphoproliferative diseases: association with polymorphisms of IL28B and TLR2. Oncotarget. 2016;7:37487-97.

22. Gouas D, Shi H, Hainaut P. The aflatoxin-induced TP53 mutation at codon 249 (R249S): biomarker of exposure, early detection and target for therapy. Cancer Lett. 2009;286:29-37.

23. Imbeaud S, Ladeiro Y, Zucman-Rossi J. Identification of novel oncogenes and tumor suppressors in hepatocellular carcinoma. Semin Liver Dis. 2010;30:75-86.

24. Nault JC, Zucman-Rossi J. Genetics of hepatobiliary carcinogenesis. Semin Liver Dis. 2011;31:173-87.

25. Fujimoto A, Totoki Y, Abe T, Boroevich KA, Hosoda F, Nguyen HH, Aoki M, Hosono N, Kubo M, Miya F, Arai Y, Takahashi H, Shirakihara T, Nagasaki M, Shibuya T, Nakano K, Watanabe-Makino K, Tanaka H, Nakamura H, Kusuda J, Ojima H, Shimada K, Okusaka T, Ueno M, Shigekawa Y, Kawakami Y, Arihiro K, Ohdan H, Gotoh K, Ishikawa O, Ariizumi S, Yamamoto M, Yamada T, Chayama K, Kosuge T, Yamaue H, Kamatani N, Miyano S, Nakagama H, Nakamura Y, Tsunoda T, Shibata T, Nakagawa H. Whole-genome sequencing of liver cancers identifies etiological influences on mutation patterns and recurrent mutations in chromatin regulators. Nat Genet. 2012:44:760-4.

26. Huang J, Deng Q, Wang Q, Li KY, Dai JH, Li N, Zhu ZD, Zhou B, Liu XY, Liu RF, Fei QL, Chen H, Cai B, Zhou B, Xiao HS, Qin LX, Han ZG. Exome sequencing of hepatitis $B$ virus-associated hepatocellular carcinoma. Nat Genet. 2012;44:1117-21.

27. Weinhold N, Jacobsen A, Schultz N, Sander C, Lee W. Genome-wide analysis of noncoding regulatory mutations in cancer. Nat Genet. 2014;46:1160-5.

28. Takai H, Smogorzewska A, de LT. DNA damage foci at dysfunctional telomeres. Curr Biol. 2003;13:1549-56.

29. Aubert G, Lansdorp PM. Telomeres and aging. Physiol Rev. 2008;88:557-79.

30. Schulze K, Imbeaud S, Letouze E, Alexandrov LB, Calderaro J, Rebouissou S, Couchy G, Meiller C, Shinde J, Soysouvanh F, Calatayud AL, Pinyol R, Pelletier L, Balabaud C, Laurent A, Blanc JF, Mazzaferro V, Calvo F, Villanueva A, Nault JC, Bioulac-Sage P, Stratton MR, Llovet JM, Zucman-Rossi J. Exome sequencing of hepatocellular carcinomas identifies new mutational signatures and potential therapeutic targets. Nat Genet. 2015;47:505-11.

31. Totoki Y, Tatsuno K, Covington KR, Ueda H, Creighton CJ, Kato M, Tsuji S, Donehower LA, Slagle BL, Nakamura H, Yamamoto S, Shinbrot E, Hama N, Lehmkuhl M, Hosoda F, Arai Y, Walker K, Dahdouli M, Gotoh K, Nagae G, Gingras MC, Muzny DM, Ojima H, Shimada K, Midorikawa Y, Goss JA, Cotton R, Hayashi A, Shibahara J, Ishikawa S, Guiteau J, Tanaka M, Urushidate T, Ohashi S, Okada N, Doddapaneni H, Wang M, Zhu Y, Dinh H, Okusaka T, Kokudo N, Kosuge T, Takayama T, Fukayama M, Gibbs RA, Wheeler DA, Aburatani $\mathrm{H}$, Shibata T. Trans-ancestry mutational landscape of hepatocellular carcinoma genomes. Nat Genet. 2014;46:1267-73.

32. Pezzuto F, Izzo F, Buonaguro L, Annunziata C, Tatangelo F, Botti G, Buonaguro FM, Tornesello ML: Tumor specific mutations in TERT promoter and CTNNB1 gene in hepatitis $B$ and hepatitis $C$ related hepatocellular carcinoma. Oncotarget 2016.

33. Xu D, Dwyer J, Li H, Duan W, Liu JP. Ets2 maintains hTERT gene expression and breast cancer cell proliferation by interacting with c-Myc. J Biol Chem. 2008;283:23567-80.

34. Park CK, Lee SH, Kim JY, Kim JE, Kim TM, Lee ST, Choi SH, Park SH, Kim IH. Expression level of hTERT is regulated by somatic mutation and common single nucleotide polymorphism at promoter region in glioblastoma. Oncotarget. 2014:5:3399-407.

35. Wright WE, Piatyszek MA, Rainey WE, Byrd W, Shay JW. Telomerase activity in human germline and embryonic tissues and cells. Dev Genet. 1996;18:173-9.
36. Levy MZ, Allsopp RC, Futcher AB, Greider CW, Harley CB. Telomere endreplication problem and cell aging. J Mol Biol. 1992;225:951-60.

37. Kim NW, Piatyszek MA, Prowse KR, Harley CB, West MD, Ho PL, Coviello GM, Wright WE, Weinrich SL, Shay JW. Specific association of human telomerase activity with immortal cells and cancer. Science. 1994;266:2011-5.

38. Masutomi K, Yu EY, Khurts S, Ben-Porath I, Currier JL, Metz GB, Brooks MW, Kaneko S, Murakami S, DeCaprio JA, Weinberg RA, Stewart SA, Hahn WC. Telomerase maintains telomere structure in normal human cells. Cell. 2003; 114:241-53.

39. Blackburn EH. Telomere states and cell fates. Nature. 2000;408:53-6.

40. Ramlee MK, Wang J, Toh WX, Li S. Transcription Regulation of the Human Telomerase Reverse Transcriptase (hTERT) Gene. Genes (Basel). 2016;7:50.

41. De LT. How shelterin solves the telomere end-protection problem. Cold Spring Harb Symp Quant Biol. 2010;75:167-77.

42. Makarov VL, Hirose Y, Langmore JP. Long G tails at both ends of human chromosomes suggest a C strand degradation mechanism for telomere shortening. Cell. 1997;88:657-66.

43. Wright WE, Tesmer VM, Huffman KE, Levene SD, Shay JW. Normal human chromosomes have long G-rich telomeric overhangs at one end. Genes Dev. 1997;11:2801-9.

44. Donati B, Valenti L. Telomeres, NAFLD and Chronic Liver Disease. Int J Mol Sci. 2016;17:383.

45. Wiemann SU, Satyanarayana A, Tsahuridu M, Tillmann HL, Zender L, Klempnauer J, Flemming P, Franco S, Blasco MA, Manns MP, Rudolph KL. Hepatocyte telomere shortening and senescence are general markers of human liver cirrhosis. FASEB J. 2002;16:935-42.

46. Kitada T, Seki S, Kawakita N, Kuroki T, Monna T. Telomere shortening in chronic liver diseases. Biochem Biophys Res Commun. 1995;211:33-9.

47. Carulli $L$, Anzivino C. Telomere and telomerase in chronic liver disease and hepatocarcinoma. World J Gastroenterol. 2014;20:6287-92.

48. Lee CM, Hsu CY, Eng HL, Huang WS, Lu SN, Changchien CS, Chen CL, Cho $\mathrm{CL}$. Telomerase activity and telomerase catalytic subunit in hepatocellular carcinoma. Hepatogastroenterology. 2004;51:796-800.

49. Nakayama J, Tahara H, Tahara E, Saito M, Ito K, Nakamura H, Nakanishi T, Tahara E, Ide T, Ishikawa F. Telomerase activation by hTRT in human normal fibroblasts and hepatocellular carcinomas. Nat Genet. 1998;18:65-8.

50. Nouso K, Urabe Y, Higashi T, Nakatsukasa H, Hino N, Ashida K, Kinugasa N, Yoshida K, Uematsu S, Tsuji T. Telomerase as a tool for the differential diagnosis of human hepatocellular carcinoma. Cancer. 1996;78:232-6.

51. Oh BK, Kim H, Park YN, Yoo JE, Choi J, Kim KS, Lee JJ, Park C. High telomerase activity and long telomeres in advanced hepatocellular carcinomas with poor prognosis. Lab Invest. 2008;88:144-52.

52. Ferber MJ, Montoya DP, Yu C, Aderca I, McGee A, Thorland EC, Nagorney DM, Gostout BS, Burgart LJ, Boix L, Bruix J, McMahon BJ, Cheung TH, Chung TK, Wong YF, Smith DI, Roberts LR. Integrations of the hepatitis B virus (HBV) and human papillomavirus (HPV) into the human telomerase reverse transcriptase (hTERT) gene in liver and cervical cancers. Oncogene. 2003;22:3813-20.

53. Horikawa I, Barrett JC. cis-Activation of the human telomerase gene (hTERT) by the hepatitis B virus genome. J Natl Cancer Inst. 2001:93:1171-3.

54. Levrero M, Zucman-Rossi J. Mechanisms of HBV-induced hepatocellular carcinoma. J Hepatol. 2016;64:S84-101.

55. Brechot C, Pourcel C, Louise A, Rain B, Tiollais P. Presence of integrated hepatitis $B$ virus DNA sequences in cellular DNA of human hepatocellular carcinoma. Nature. 1980;286:533-5.

56. Hai H, Tamori A, Kawada N. Role of hepatitis B virus DNA integration in human hepatocarcinogenesis. World J Gastroenterol. 2014;20:6236-43.

57. Sung WK, Zheng $H, L i S$, Chen R, Liu X, Li Y, Lee NP, Lee WH, Ariyaratne PN, Tennakoon C, Mulawadi FH, Wong KF, Liu AM, Poon RT, Fan ST, Chan KL, Gong Z, Hu Y, Lin Z, Wang G, Zhang Q, Barber TD, Chou WC, Aggarwal A, Hao K, Zhou W, Zhang C, Hardwick J, Buser C, Xu J, Kan Z, Dai H, Mao M, Reinhard C, Wang J, Luk JM. Genome-wide survey of recurrent HBV integration in hepatocellular carcinoma. Nat Genet. 2012:44:765-9.

58. Zhao LH, Liu X, Yan HX, Li WY, Zeng X, Yang Y, Zhao J, Liu SP, Zhuang XH, Lin C, Qin CJ, Zhao Y, Pan ZY, Huang G, Liu H, Zhang J, Wang RY, Yang Y, Wen W, Lv GS, Zhang HL, Wu H, Huang S, Wang MD, Tang L, Cao HZ, Wang L, Lee TP, Jiang H, Tan YX, Yuan SX, Hou GJ, Tao QF, Xu QG, Zhang XQ, Wu MC, Xu X, Wang J, Yang HM, Zhou WP, Wang HY. Genomic and oncogenic preference of HBV integration in hepatocellular carcinoma. Nat Commun. 2016;7:12992. doi:10.1038/ncomms12992:12992. 
59. Yang X, Wu L, Lin J, Wang A, Wan X, Wu Y, Robson SC, Sang X, Zhao H: Distinct hepatitis $B$ virus integration patterns in hepatocellular carcinoma and adjacent normal liver tissue. Int J Cancer 2016:10.

60. Cevik D, Yildiz G, Ozturk M. Common telomerase reverse transcriptase promoter mutations in hepatocellular carcinomas from different geographical locations. World J Gastroenterol. 2015;21:311-7.

61. Killela PJ, Reitman ZJ, Jiao Y, Bettegowda C, Agrawal N, Diaz Jr LA, Friedman AH, Friedman H, Gallia GL, Giovanella BC, Grollman AP, He TC, He Y, Hruban RH, Jallo Gl, Mandahl N, Meeker AK, Mertens F, Netto GJ, Rasheed BA, Riggins GJ, Rosenquist TA, Schiffman M, Shih I, Theodorescu D, Torbenson MS, Velculescu VE, Wang TL, Wentzensen N, Wood LD, Zhang M, McLendon RE, Bigner DD, Kinzler KW, Vogelstein B, Papadopoulos N, Yan H. TERT promoter mutations occur frequently in gliomas and a subset of tumors derived from cells with low rates of self-renewal. Proc Natl Acad Sci U S A. 2013:110:6021-6.

62. Bojesen SE, Pooley KA, Johnatty SE, Beesley J, Michailidou K, Tyrer JP, Edwards SL, Pickett HA, Shen HC, Smart CE, Hillman KM, Mai PL, Lawrenson K, Stutz MD, Lu Y, Karevan R, Woods N, Johnston RL, French JD, Chen X, Weischer M, Nielsen SF, Maranian MJ, Ghoussaini M, Ahmed S, Baynes C, Bolla MK, Wang Q, Dennis J, McGuffog L, Barrowdale D, Lee A, Healey S, Lush M, Tessier DC, Vincent D, Bacot F, Vergote I, Lambrechts S, Despierre E, Risch HA, Gonzalez-Neira A, Rossing MA, Pita G, Doherty JA, Alvarez N, Larson MC, Fridley BL, Schoof N, Chang-Claude J, Cicek MS, Peto J, Kalli KR, Broeks A, Armasu SM, Schmidt MK, Braaf LM, Winterhoff B, Nevanlinna H, Konecny GE, Lambrechts D, Rogmann L, Guenel P, Teoman A, Milne RL, Garcia JJ, Cox A, Shridhar V, Burwinkel B, Marme F, Hein R, Sawyer EJ, Haiman CA, Wang-Gohrke S, Andrulis IL, Moysich KB, Hopper JL, Odunsi K, Lindblom A, Giles GG, Brenner H, Simard J, Lurie G, Fasching PA, Carney ME, Radice P, Wilkens LR, Swerdlow A, Goodman MT, Brauch $H$, Garcia-Closas M, Hillemanns P, Winqvist R, Durst M, Devilee $P$, Runnebaum I, Jakubowska A, Lubinski J, Mannermaa A, Butzow R, Bogdanova NV, Dork T, Pelttari LM, Zheng W, Leminen A, Anton-Culver $H$, Bunker CH, Kristensen V, Ness RB, Muir K, Edwards R, Meindl A, Heitz F, Matsuo K, Du BA, Wu AH, Harter P, Teo SH, Schwaab I, Shu XO, Blot W, Hosono S, Kang D, Nakanishi T, Hartman M, Yatabe Y, Hamann U, Karlan BY, Sangrajrang S, Kjaer SK, Gaborieau V, Jensen A, Eccles D, Hogdall E, Shen CY, Brown J, Woo YL, Shah M, Azmi MA, Luben R, Omar SZ, Czene K, Vierkant RA, Nordestgaard BG, Flyger H, Vachon C, Olson JE, Wang X, Levine DA, Rudolph A, Weber RP, Flesch-Janys D, Iversen E, Nickels S, Schildkraut JM, Silva IS, Cramer DW, Gibson L, Terry KL, Fletcher O, Vitonis AF, van der Schoot CE, Poole EM, Hogervorst FB, Tworoger SS, Liu J, Bandera EV, Li J, Olson SH, Humphreys K, Orlow I, Blomqvist C, RodriguezRodriguez L, Aittomaki K, Salvesen HB, Muranen TA, Wik E, Brouwers B, Krakstad C, Wauters E, Halle MK, Wildiers H, Kiemeney LA, Mulot C, Aben KK, Laurent-Puig P, Altena AM, Truong T, Massuger LF, Benitez J, Pejovic T, Perez JI, Hoatlin M, Zamora MP, Cook LS, Balasubramanian SP, Kelemen LE, Schneeweiss A, Le ND, Sohn C, Brooks-Wilson A, Tomlinson I, Kerin MJ, Miller N, Cybulski C, Henderson BE, Menkiszak J, Schumacher F, Wentzensen N, Le ML, Yang HP, Mulligan AM, Glendon G, Engelholm SA, Knight JA, Hogdall CK, Apicella C, Gore M, Tsimiklis H, Song H, Southey MC, Jager A, den Ouweland AM, Brown R, Martens JW, Flanagan JM, Kriege M, Paul J, Margolin S, Siddiqui N, Severi G, Whittemore AS, Baglietto L, McGuire V, Stegmaier C, Sieh W, Muller H, Arndt V, Labreche F, Gao YT, Goldberg MS, Yang G, Dumont M, McLaughlin JR, Hartmann A, Ekici AB, Beckmann MW, Phelan CM, Lux MP, Permuth-Wey J, Peissel B, Sellers TA, Ficarazzi F, Barile M, Ziogas A. Multiple independent variants at the TERT locus are associated with telomere length and risks of breast and ovarian cancer. Nat Genet. 2013;45:371-2.

63. Zhong R, Liu L, Zou L, Zhu Y, Chen W, Zhu B, Shen N, Rui R, Long L, Ke J, Lu $X$, Zhang T, Zhang Y, Wang Z, Liu L, Sun Y, Cheng L, Miao X. Genetic variations in TERT-CLPTM1L locus are associated with risk of lung cancer in Chinese population. Mol Carcinog. 2013;52 Suppl 1:E118-26.

64. Abecasis GR, Auton A, Brooks LD, DePristo MA, Durbin RM, Handsaker RE, Kang HM, Marth GT, McVean GA. An integrated map of genetic variation from 1,092 human genomes. Nature. 2012:491:56-65.

65. Ko E, Seo HW, Jung ES, Kim BH, Jung G. The TERT promoter SNP rs 2853669 decreases E2F1 transcription factor binding and increases mortality and recurrence risks in liver cancer. Oncotarget. 2016;7:684-99.

66. Castelo-Branco P, Choufani S, Mack S, Gallagher D, Zhang C, Lipman T, Zhukova N, Walker EJ, Martin D, Merino D, Wasserman JD, Elizabeth C, Alon N, Zhang L, Hovestadt V, Kool M, Jones DT, Zadeh G, Croul S, Hawkins C,
Hitzler J, Wang JC, Baruchel S, Dirks PB, Malkin D, Pfister S, Taylor MD, Weksberg $\mathrm{R}$, Tabori U. Methylation of the TERT promoter and risk stratification of childhood brain tumours: an integrative genomic and molecular study. Lancet Oncol. 2013;14:534-42.

67. Dessain SK, Yu H, Reddel RR, Beijersbergen RL, Weinberg RA. Methylation of the human telomerase gene CpG island. Cancer Res. 2000;60:537-41.

68. Kojima H, Yokosuka O, Imazeki F, Saisho H, Omata M. Telomerase activity and telomere length in hepatocellular carcinoma and chronic liver disease. Gastroenterology. 1997;112:493-500.

69. Nault JC, Mallet M, Pilati C, Calderaro J, Bioulac-Sage P, Laurent C, Laurent A, Cherqui D, Balabaud C, Zucman-Rossi J. High frequency of telomerase reversetranscriptase promoter somatic mutations in hepatocellular carcinoma and preneoplastic lesions. Nat Commun. 2013;4:2218.

70. Hsu IC, Metcalf RA, Sun T, Welsh JA, Wang NJ, Harris CC. Mutational hotspot in the p53 gene in human hepatocellular carcinomas. Nature. 1991:350:427-8.

71. Hussain SP, Schwank J, Staib F, Wang XW, Harris CC. TP53 mutations and hepatocellular carcinoma: insights into the etiology and pathogenesis of liver cancer. Oncogene. 2007;26:2166-76.

72. Gouas DA, Shi H, Hautefeuille AH, Ortiz-Cuaran SL, Legros PC, Szymanska KJ, Galy O, Egevad LA, Bedi-Ardekani B, Wiman KG, Hantz O, de FC C, Chemin IA, Hainaut PL. Effects of the TP53 p.R249S mutant on proliferation and clonogenic properties in human hepatocellular carcinoma cell lines: interaction with hepatitis B virus X protein. Carcinogenesis. 2010;31:1475-82.

73. Chen YL, Jeng YM, Chang CN, Lee HJ, Hsu HC, Lai PL, Yuan RH. TERT promoter mutation in resectable hepatocellular carcinomas: a strong association with hepatitis $C$ infection and absence of hepatitis B infection. Int J Surg. 2014;12:659-65.

74. Yang X, Guo X, Chen Y, Chen G, Ma Y, Huang K, Zhang Y, Zhao Q, Winkler CA, An P, Lyu J. Telomerase reverse transcriptase promoter mutations in hepatitis B virus-associated hepatocellular carcinoma. Oncotarget. 2016;7: 27838-47.

75. Huang DS, Wang Z, He XJ, Diplas BH, Yang R, Killela PJ, Meng Q, Ye ZY, Wang W, Jiang XT, Xu L, He XL, Zhao ZS, Xu WJ, Wang HJ, Ma YY, Xia YJ, Li L, Zhang RX, Jin T, Zhao ZK, Xu J, Yu S, Wu F, Liang J, Wang S, Jiao Y, Yan H, Tao HQ. Recurrent TERT promoter mutations identified in a large-scale study of multiple tumour types are associated with increased TERT expression and telomerase activation. Eur J Cancer. 2015;51:969-76.

76. Lee SE, Chang SH, Kim WY, Lim SD, Kim WS, Hwang TS, Han HS: Frequent somatic TERT promoter mutations and CTNNB1 mutations in hepatocellular carcinoma. Oncotarget 2016

77. Ki Kim S, Ueda Y, Hatano E, Kakiuchi N, Takeda H, Goto T, Shimizu T, Yoshida K, Ikura Y, Shiraishi Y, Chiba K, Tanaka H, Miyano S, Uemoto S, Chiba T, Ogawa S, Marusawa H. TERT promoter mutations and chromosome $8 p$ loss are characteristic of nonalcoholic fatty liver disease-related hepatocellular carcinoma. Int J Cancer. 2016;139:2512-8.

78. Quaas A, Oldopp T, Tharun L, Klingenfeld C, Krech T, Sauter G, Grob TJ. Frequency of TERT promoter mutations in primary tumors of the liver. Virchows Arch. 2014;465:673-7.

\section{Submit your next manuscript to BioMed Central and we will help you at every step:}

- We accept pre-submission inquiries

- Our selector tool helps you to find the most relevant journal

- We provide round the clock customer support

- Convenient online submission

- Thorough peer review

- Inclusion in PubMed and all major indexing services

- Maximum visibility for your research

Submit your manuscript at www.biomedcentral.com/submit 